\title{
Germline TP53 Testing in Breast Cancers: Why, When and How?
}

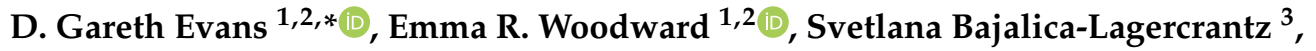 \\ Carla Oliveira ${ }^{4,5,6} \mathbb{D}$ and Thierry Frebourg $7,8, *$ \\ 1 Manchester Centre for Genomic Medicine, Division of Evolution and Genomic Sciences, \\ University of Manchester, Manchester M13 9WL, UK; Emma.Woodward@mft.nhs.uk \\ 2 Manchester Centre for Genomic Medicine St Mary's Hospital, Manchester University Hospitals NHS \\ Foundation Trust, Manchester M13 9WL, UK \\ 3 Hereditary Cancer Unit, Department of Clinical Genetics, Karolinska University Hospital, \\ SE-17176 Stockholm, Sweden; svetlana.lagercrantz@ki.se \\ 4 i3S-Instituto de Investigação e Inovação em Saúde, Universidade do Porto, 4200-135 Porto, Portugal; \\ carlaol@i3s.up.pt \\ 5 Ipatimup-Institute of Molecular Pathology and Immunology of the University of Porto, \\ 4200-135 Porto, Portugal \\ 6 Porto Comprehensive Cancer Center, 4200-072 Porto, Portugal \\ 7 Department of Genetics, Rouen University Hospital, Normandy Centre for Genomic and \\ Personalized Medicine, 76000 Rouen, France \\ 8 Inserm U1245, Normandie University, UNIROUEN, Normandy Centre for Genomic and \\ Personalized Medicine, 76183 Rouen, France \\ * Correspondence: Gareth.Evans@mft.nhs.uk (D.G.E.); frebourg@chu-rouen.fr (T.F.)
}

Received: 24 November 2020; Accepted: 8 December 2020; Published: 14 December 2020

Simple Summary: TP53 variants detected in blood represent a main genetic cause of breast cancers occurring before 31 years of age. TP53 being included in most of the cancer gene panels, patients with breast cancer are offered germline TP53 testing, independently of the age of tumour onset and familial history. Interpretation of TP53 variants is remarkably complex, and detection of a germline disease-causing TP53 variant in a breast cancer patient has drastic medical consequences: radiotherapy contributing to the development of subsequent tumours should be, if possible, avoided. In her family, variant carriers should be offered annual follow-up, including whole-body MRI. Therefore, we consider that, in breast cancer patients, germline TP53 testing should be performed before treatment and that the decision of TP53 testing should not be systematic but based on the age of tumour onset, type of breast cancer, personal and familial history of cancer.

\begin{abstract}
Germline TP53 variants represent a main genetic cause of breast cancers before 31 years of age. Development of cancer multi-gene panels has resulted in an exponential increase of germline TP53 testing in breast cancer patients. Interpretation of TP53 variants, which are mostly missense, is complex and requires excluding clonal haematopoiesis and circulating tumour DNA. In breast cancer patients harbouring germline disease-causing TP53 variants, radiotherapy contributing to the development of subsequent tumours should be, if possible, avoided and, within families, annual follow-up including whole-body MRI should be offered to carriers. We consider that, in breast cancer patients, germline TP53 testing should be performed before treatment and offered systematically only to patients with: (i) invasive breast carcinoma or ductal carcinoma in situ (DCIS) before 31; or (ii) bilateral or multifocal or HER2+ invasive breast carcinoma/DCIS or phyllode tumour before 36; or (iii) invasive breast carcinoma before 46 and another TP53 core tumour (breast cancer, soft-tissue sarcoma, osteosarcoma, central nervous system tumour, adrenocortical carcinoma); or (iv) invasive breast carcinoma before 46 and one first- or second-degree relative with a TP53 core tumour before 56. In contrast, women presenting with breast cancer after 46 , without suggestive personal or familial history, should not be tested for TP53.
\end{abstract}


Keywords: breast cancer; gene panels; TP53; variant; interpretation; Li-Fraumeni syndrome; heritable TP53-related cancer syndrome

\section{Introduction}

The development of cancer multi-gene panels has resulted in an exponential increase of TP53 testing in patients with breast cancers, as TP53 is included in most of the commercial or academic cancer gene panels. In 1990, heterozygous germline TP53 variants were shown to be the genetic cause of Li-Fraumeni syndrome (LFS) [1-4]. LFS is typically characterized by a strong familial clustering of early-onset malignancies and core tumours: soft-tissue sarcomas (STS), osteosarcomas (OS), adrenocortical carcinomas (ACC), central nervous system (CNS) tumours and very early-onset female breast cancers, commonly occurring before 31 years. Thirty years after the characterization of LFS molecular basis, testing children with malignancies or adult females with very early-onset breast cancers without the aspect of family history has shown that familial history of cancer is not mandatory to identify a germline disease-causing TP53 variant [5-12]. This is explained by the fact that de novo TP53 variants are not uncommon and penetrance of the variants is incomplete [10-13]. New criteria, designated the Chompret criteria, have been sequentially updated in order to facilitate the clinical recognition of the syndrome and to cover its clinical heterogeneity [14]. The concept of a heritable TP53-related cancer (hTP53rc) syndrome has, therefore emerged in order to highlight this clinical diversity [14].

As indicated in Table 1, Chompret criteria include, in particular, (i) the familial aggregation of a patient with breast cancer before 46 years and at least one first- or second-degree relative with a TP53 core tumour before 56 years, (ii) the development of breast cancer before 46 years and a second tumour and (ii) the occurrence of very early-onset breast cancer, occurring before 31 years.

Table 1. Updated Chompret Criteria for Germline TP53 Testing [14].

\begin{tabular}{cl}
\hline \multicolumn{1}{c}{ Presentation } & \multicolumn{1}{c}{ Criteria } \\
\hline Familial presentation & $\begin{array}{l}\text { Patient with a TP53 core tumour (breast cancer, soft-tissue sarcoma, } \\
\text { osteosarcoma, central nervous system tumour, adrenocortical } \\
\text { carcinoma) before 46 years AND at least one first- or second-degree } \\
\text { relative with a core tumour before 56 years }\end{array}$ \\
\hline Multiple primitive tumours & $\begin{array}{l}\text { Patient with multiple tumours, including 2 TP53 core tumours, the } \\
\text { first of which occurred before 46 years, irrespective of family history }\end{array}$ \\
\hline Rare tumours & $\begin{array}{l}\text { Patient with adrenocortical carcinoma, choroid plexus carcinoma, or } \\
\text { rhabdomyosarcoma of embryonal anaplastic subtype, } \\
\text { irrespective of family history }\end{array}$ \\
\hline Very early-onset breast cancer & Breast cancer before 31 years, irrespective of family history \\
\hline
\end{tabular}

TP53 testing is now offered to patients with breast cancers outside these criteria, using cancer gene panels, sometimes via their oncologist or surgeon or even through direct to consumer testing, rather than through genetic counselling services. In this context, we review here the complexity both of TP53 variant interpretation and cancer risk estimation in variant carriers and the medical consequences of germline disease-causing TP53 variant identification in breast cancer patients.

\section{Interpretation of Germline TP53 Variants}

When a TP53 variant is detected from blood in a patient with cancer, two questions should be addressed before considering that the detected variant is the cause of the underlying cancer: (i) Can the detected TP53 variant be classified as a disease-causing variant? (ii) What is the mutant allele frequency in the blood sample, and is it confined to peripheral blood cells? These questions are clinically 
critical, considering the consequences for the patients and families of the identification of a germline disease-causing TP53 variant.

\subsection{Disease-Causing Variants}

Most of the germline disease-causing TP53 variants are missense and occur within the large central DNA binding domain of the protein [12]. A subclass of these missense variants acts in a dominant-negative fashion resulting in mutant proteins that form tetramers with wild-type p53 and thereby inhibit the transcriptional activity of the wild-type protein [12]. As many missense variants may have no biological impact, interpretation of germline TP53 variants requires expertise to ensure proper classification, according to the American College of Medical Genetics and Genomics (ACMG)/ Association for Molecular Pathology (AMP) international guidelines: class one, non-pathogenic; class two, likely non-pathogenic; class three, variants of uncertain significance (VUS); class four: likely-pathogenic or class five: pathogenic [15]. As for other genes involved in Mendelian diseases, classification of germline TP53 variants is based on several arguments including the frequency of the variants in the general population, as recorded in the Genome Aggregation Database [16]; bioinformatics predictions of the variant impact on protein or RNA splicing, using different algorithms; phenotypical and segregation data. Furthermore, interpretation of TP53 variants also relies on several functional analyses. The first assay commonly used for TP53 variant interpretation is based on the cloning of human TP53 cDNAs in yeast expression vectors and the measurement of p53 transcriptional activity in yeast strains containing reporter plasmids including different $\mathrm{p} 53$ binding sites [17]. In the yeast assay, p53 variants are classified as functional, not functional, or partially functional according to the level of transcriptional activity quantified using the different reporter plasmids. Two high throughput p53 functional assays have recently been developed in human cancer cell lines. In the first assay, Kotler et al. [18] generated a synthetic library of TP53 variants located within the p53 DNA-binding domain and quantified their anti-proliferative activity in a p53-null cancer cell line. In this assay, TP53 variants are categorized as variants retaining wild-type p53 anti-proliferative activity (wild-type TP53-like or functional variants) or as variants disrupting this activity (non-functional variants). In the second assay, Giacomelli et al. [19] tested the ability of TP53 variants generated by saturation mutagenesis (i) to restore the survival of a p53-null cell line exposed to high doses of DNA damaging agents, in order to detect loss of function (LOF) variants and (ii) to induce in p53-wild-type cells resistance to Nutlin-3, in order to detect variants with dominant-negative effect (DNE). The TP53 International Agency for Research on Cancer (IARC) database) has aggregated the results from functional assays and curated both somatic and germline variants [20]. A p53 assay directly performed on blood and based on the quantification of the p53-mediated transcriptional response to DNA damage in the genetic context of patients has recently been developed in order to facilitate the interpretation of variants, which remain of uncertain significance [21]. Specific ACMG/AMP criteria for germline TP53 variant classification have been defined by a TP53 variant curation expert panel, under the umbrella of ClinGen. These specific criteria indicate that at least two different functional analyses are required to predict pathogenicity [22].

The complexity of germline TP53 variant interpretation can be seen by the potential for 'over-classification' of TP53 variants resulting in a frequency of pathogenic or likely-pathogenic variants as high as 1 in 500 in the control database gnomAD [23], whereas a more parsimonious approach provides a more likely 1 in 5000 frequency [24,25]. Over-classification of TP53 variants has, in particular, resulted in almost certainly overstated risk of colorectal cancer in LFS [26], with one report misclassifying four/six germline variants as pathogenic or likely-pathogenic [27]. As such it can be seen that accurate variant classification is vital when dealing with TP53 variants identified on germline testing. This process is dynamic as classification should be updated according to the growing knowledge and curated databases. A significant fraction of germline TP53 variants detected by medical laboratories remains of uncertain significance (class three). Only pathogenic or likely-pathogenic variants (the difference between these two classes being particular subtle for TP53 and distinction 
requires specific expertise) should be considered and used in a medical setting. Both types of variants are designated in this manuscript as disease-causing variants.

\subsection{Mosaic Variants Versus Clonal Haematopoiesis and Circulating Tumour DNA}

The implementation of Next-Generation sequencing (NGS) in diagnostic laboratories has greatly improved, thanks to the depth of sequencing, the detection of mutant alleles in a small fraction of genomic DNA extracted from blood. This can be extremely useful in identifying mosaic variants in monogenic conditions [28]. The presence of true mosaic TP53 alterations should be considered in patients with tumours strongly suggestive of a disease-causing TP53 variant, such as childhood ACC, choroid plexus carcinoma, breast cancer before 31 years of age or with multiple primary tumours belonging to the TP53 core tumour spectrum [13].

However, there are two particular pitfalls in TP53 testing. Whilst true 'mosaicism' is not an infrequent occurrence in TP53 where multiple tissues have low levels of the variant, a more frequent cause of detected low allele frequency is clonal haematopoiesis of indeterminate potential (CHIP) [29-32]. CHIP corresponds to the expansion of a mutant hematopoietic stem and progenitor cell and is associated with increased risks of haematological neoplasms, including myelodysplastic syndromes and acute myeloid leukaemia. The TP53 gene is one of the most frequently mutated genes observed in CHIP. CHIP was first reported in patients over 70 years of age but can be detected from 30 years of age. The frequency of CHIP increases with age, tobacco use and exposure to chemo- or radiotherapy. CHIP has recently come to the fore in the context of the exponential development of gene panel testing performed in particular in cancer patients older than 40 years, who smoke or have undergone oncological treatment (e.g., 60 years+ women with breast cancer undergoing panel testing after radiotherapy). Therefore, when a TP53 variant is detected in a small fraction of NGS reads from genomic blood DNA, it is critical to confirm the presence of the variant in the tumour and in another tissue without mononuclear cells, such as hair follicle or skin biopsy [14]. The detection, in the tumour, of a loss of heterozygosity (LOH) affecting the wild-type TP53 allele will constitute a strong argument in favour of the causal role of the detected TP53 variant in tumour development and the reality of the mosaicism. If the variant is not detected within the tumour (best tested on sections without infiltration with lymphocytes or macrophages) or other tissues, clonal haematopoiesis is by far the most likely answer. CHIP should be suspected, in particular, when a TP53 variant is found in a clinical context not usually associated with germline TP53 [29,30].

The second pitfall, when mutant alleles are detected in a minor fraction of NGS reads, corresponds to circulating tumour DNA (ctDNA), commonly observed in patients with metastatic cancers. For instance, the detection in a small fraction of NGS reads of a TP53 variant in the DNA extracted from a patient with metastatic ovarian cancer will not correspond to true mosaicism but very likely to ctDNA [33], considering the very high frequency of somatic TP53 alterations in these malignancies $(>95 \%)$. As patients with ovarian cancers are commonly tested using panels, including TP53, this situation is becoming frequent.

Therefore, the interpretation of a TP53 variant detected in a small fraction of reads in a breast cancer patient requires careful analysis integrating the type and stage of the tumour, the age of the patient, and the treatments and will often require complementary genetic investigations performed on other tissues.

\section{Cancer Risk Associated with Germline Disease-Causing TP53 Variants}

Another area of difficulty concerning TP53 variant carriers is estimating their cancer risk or penetrance associated with each specific TP53 variant. The cumulative cancer risk associated with germline disease-causing TP53 variants was initially calculated mainly from familial cases and was estimated to $73 \%-100 \%$ by age 70 , with risks close to $100 \%$ in women [34-36]. There is nonetheless a clear ascertainment bias leading to an overestimation of disease penetrance when evaluating penetrance 
from cases. As such, there is no accurate assessment of cancer risk as so few truly prospective studies have been carried out for long enough periods.

What is clear is that, in germline TP53 disease-causing variant carriers, female breast cancer represents the main cancer risk. Breast cancer risk increases significantly after the second decade, is very high under the age 31 close to $20 \%-30 \%$ on the basis of the Breast cancer RIsk after Diagnostic GEne Sequencing (BRIDGES) study [37], reaches a peak between 25-35 years, and this does tally with estimates from kindreds [38]. This risk drops after 40 years of age based on the relative frequency of TP53 carriers identified $[37,39,40]$, and cumulative risk reaches a plateau before $60[35,36,38]$. For instance, of 65 known TP53 carriers with breast cancer in the Genomic Medicine Centre in Manchester 32/65 occurred aged $<31(49 \%), 24(37 \%)$ occurred aged 31-39, 5 (7.5\%) aged 40-44 and only 3/65 (4.5\%) over age 45 . It is less clear what the overall penetrance is for breast cancer. Although cumulative risk estimates to age 80 for female breast cancer of over $90 \%$ have been published [38], these likely suffer from ascertainment and survival bias with many carriers dying from other malignancies at young ages. There is clearly a very high rate of contralateral breast cancer approaching $4 \%-7 \%$ annually and significantly higher than BRCA1 or BRCA2 in those diagnosed aged $<35$ [41].

It is also clear that penetrance of germline disease-causing TP53 variants is not only incomplete but variable. The molecular bases of the penetrance variability remain to be characterized. One factor explaining, at least in part, this variability is the type of the variant itself. As explained previously, many missense variants are classified as dominant-negative due to their ability to complex and reduce the transcriptional activity of wild-type p53 protein, which normally acts as a tetramer. These dominant-negative missense TP53 variants are predominantly detected in families with childhood malignancies and are generally more penetrant in childhood than the other types of alterations. In contrast, typical loss of function variants (frameshift or nonsense variants, splicing variants, large genomic rearrangements), and non-dominant-negative missense variants, are predominantly identified in families with mostly adult cancers and appear to have a lower disease penetrance in childhood [12]. A particularly important example of a low penetrant, but still pathogenic variant, is the non-dominant-negative missense p.Arg337His variant, present in $0.3 \%$ of the Southern Brazilian population [42-45]. The lower penetrance of these variants may be explained by a less drastic impact of p53 transcriptional activity, as compared to the dominant missense variants [46]. However, it should be highlighted here that penetrance is a dynamic process that should be expressed as a curve according to age. Therefore, germline disease-causing TP53 variants designated as low penetrant in childhood, such as the canonical p.Arg337His variant, can nevertheless be associated with a high cumulative breast cancer risk up to $63 \%$ in adults as shown by recent results obtained in the Brazilian population (Maria-Isabel Achatz, personal communication). The variability in the age of tumour-onset among relatives harbouring the same germline TP53 variant clearly shows that the penetrance also depends from modifier factors that can be either genetic or environmental and their identification in the future would allow a more personalized clinical management of TP53 variant carriers.

\section{Features of Breast Tumours in TP53 Variant Carriers}

\subsection{Age of Tumour-Onset}

Several studies [47] have shown that, independently of the familial history, germline disease-causing TP53 alterations are identified in between 3.8\% and 7.7\% in females with breast carcinoma before 31 years of age, but a Dutch study recently reported a lower rate of $2 \%$ [48]. After 30 years, the rate of germline TP53 drops sharply, and germline TP53 variants rarely cause familial breast cancer unexplained by $B R C A 1$ or $B R C A 2[39,49,50]$. The very low rate of germline TP53 mutation detected in breast carcinoma presenting after age 30 years has recently been validated in the BRIDGES study, including 60,466 cases and 53,461 controls [37]. In the BRIDGES study, 4/346 patients $<30$ years had germline truncating TP53 variants compared to 2/53,461 controls yielding an odds ratio (OR) of 309 , contrasting with only 3/60,120 > 30 years and an OR of 1.33 (Easton D, personal communication). 


\subsection{Histopathologic Features}

The vast majority (above 90\%) of female breast cancers observed in germline disease-causing TP53 variant carriers, corresponds to invasive ductal carcinomas of no special type. The remaining cases correspond to invasive lobular carcinoma or invasive ductal/lobular carcinoma [9,40,51-54]. In contrast to $B R C A 1 / B R C A 2$ variant carriers, a high frequency of ductal carcinoma in situ (DCIS) is observed, with estimates up to $25 \%$ [52,53], and it is likely that this fraction will increase with systematic annual breast MRI in carriers. A high nuclear grade is observed in the majority of the invasive carcinoma and DCIS cases associated with germline TP53 variants, and most of the invasive carcinoma are of mSBR (modified Scarff-Bloom-Richardson) grade three [52,53]. Most of the breast carcinoma exhibits HER2 amplification and overexpression, as $60 \%-83 \%$ show HER2 positivity $[9,40,49,51-54]$ with more than $40 \%$ showing ER co-expression. However, using HER2+ as the only argument to test over 30 years of age identifies very few carriers [40]. Based on this single criterion, only $2 / 82$ breast cancer patients $<40(2.5 \%)$ had a germline TP53 pathogenic variant, $1 / 132$ aged $\leq 40$ and among women without a known family history consistent with Chompret criteria, TP53 variants were found in only 1/195 $(0.5 \%)$. Nonetheless, some weight of HER2 expression can be considered in association with other arguments suggestive of genetic determinism, such as the early age of onset, the high nuclear grade, the histological type and tumour multifocality.

Beside breast carcinomas, phyllodes tumours of the breast, which are rare mesenchymal tumours with differential malignant potential, are also strongly suggestive of a germline TP53 alteration, when they occur in patients before 36 years of age. The association between germline TP53 alterations and early-onset phyllodes tumours has been documented since 2001 by several articles $[55,56]$ and observations from different teams, and a recent study reported a mutation detection rate up to $10 \%$ [57]. Most of the reported phyllodes tumour cases associated with germline TP53 variants are malignant $[55,56]$.

\section{Treatment-Related Risks in TP53 Variant Carriers}

Germline pathogenic TP53 variant carriers have a very high risk of subsequent primary tumours, which may occur in $>40 \%$ of TP53 carriers [12,35]. Subsequent primary tumours often develop after treatment of TP53 carriers with radiation and/or genotoxic chemotherapy. The contribution of radiotherapy and conventional chemotherapy to the development of subsequent primary tumours came initially from multiple observations in kindreds and was strongly suggested by the key role of p53 in transcriptional response to DNA damage [12]. Functional studies performed ex vivo on lymphocytes have shown that radiotherapy and conventional chemotherapies, except mitotic spindle poisons, induce the p53-mediated transcriptional response to DNA damage and that this response is altered in non-malignant cells from germline disease-causing TP53 carriers [58]. Furthermore, exposure of mice, harbouring a germline alteration of one TP53 allele, to radiotherapy or genotoxic chemotherapies drastically increases tumour development risk [58]. All these data show that, unfortunately, radiotherapy and genotoxic chemotherapies used for the treatment of first cancer contribute to the development of subsequent primary tumours in TP53 variant carriers. Our conviction of this risk is re-enforced by the growing number of observations of sarcomas occurring in the radiotherapy field, in TP53 variant carrier.

Therefore, in patients with breast cancers, if the age of tumour onset, personal or familial history is suggestive of a germline pathogenic TP53 variant, testing for disease-causing TP53 variants should be carried out before starting treatment, in order to prioritize radical surgical treatment and discuss, in the framework of a multi-disciplinary team, the balance between the risk of recurrence in the absence of chemo- or radiotherapy and the risk of secondary primary tumour induced by the treatment [14]. For instance, if a disease-causing TP53 variant is identified in a young woman with invasive, T1N0 breast cancer, this will mean strongly advising for mastectomy rather than breast-conserving surgery and radiotherapy and given the high contralateral risk the option of bilateral mastectomy [14,41]. In breast cancer patients, harbouring a germline disease-causing TP53 variant and treated by radiotherapy, 
the development of sarcomas in the radiotherapy field becomes a growing issue, and their early detection should constitute a priority during their annual follow-up. In this context, the detection in a breast cancer patient of a germline TP53 variant of unknown significance is particularly challenging and should lead to an updated interpretation by an expert laboratory.

\section{Surveillance Protocols in Carriers of Germline Disease-Causing TP53 Variants}

Guidelines for surveillance of TP53 disease-causing variant carriers, based on the Toronto protocol [59], have recently been published [14,60,61]. These protocols exhibit some difference, but they all include abdominal ultrasound every 3-6 months, annual whole-body MRI (WBMRI) and annual brain MRI (the first with gadolinium enhancement) from the first year of life. Additionally, female carriers should undergo annual breast MRI from the age of 20 onwards. The option of risk-reducing mastectomy may be discussed on a case-by-case basis $[14,60]$. Several international studies, mostly performed without gadolinium-based contrast agents (GBCAs), have confirmed the efficiency of WBMRI, with an overall estimated detection rate of $7 \%$ for new and localized primary cancers on a first prevalent screen [59,62-68]. Given concerns over the accumulation of gadolinium, it is advised that only initial scans should have this on WBMRI and brain imaging [14] although this is more problematic to avoid for breast imaging. Table 2 presents the recommended follow-up according to the guidelines elaborated by the European Network, Genetic tumour risk syndromes (GENTURIS) [14].

Table 2. Surveillance Protocol in Carriers of Germline disease-causing TP53 Variants (from reference 14).

\begin{tabular}{|c|c|c|c|c|}
\hline Exam & Periodicity & Age to Start & Age to End & Condition \\
\hline \multirow{2}{*}{ Clinical examination } & Every six months & Birth & 17 years & \\
\hline & Annual & 18 years & - & \\
\hline \multirow{2}{*}{$\begin{array}{l}\text { Whole-Body MRI without } \\
\text { gadolinium enhancement }\end{array}$} & \multirow[t]{2}{*}{ Annual } & Birth & - & $\begin{array}{l}\text { TP53 variant conferring high } \\
\text { cancer risk in childhood * }\end{array}$ \\
\hline & & 18 years & - & \\
\hline Breast MRI & Annual & 20 years & Until 65 years & \\
\hline \multirow[t]{2}{*}{ Brain MRI ** } & \multirow[t]{2}{*}{ Annual } & Birth & 18 years & $\begin{array}{l}\text { TP53 variant conferring high } \\
\text { cancer risk in childhood }\end{array}$ \\
\hline & & 18 years & Until 50 years & \\
\hline Abdominal ultrasound & Every six months & Birth & Until 18 years & \\
\hline Urine steroids & Every six months & Birth & Until 18 years & $\begin{array}{l}\text { When abdominal ultrasound does } \\
\text { not allow a proper imaging of the } \\
\text { adrenal glands }\end{array}$ \\
\hline Colonoscopy & Every five years & 18 years & - & $\begin{array}{l}\text { Only if the carrier received } \\
\text { abdominal radiotherapy for the } \\
\text { treatment of a previous cancer or } \\
\text { if there is a familial history of } \\
\text { colorectal tumours suggestive of } \\
\text { an increased genetic risk }\end{array}$ \\
\hline
\end{tabular}

* A germline disease-causing TP53 variant should be considered as "high risk" in childhood if the index case has developed a childhood cancer; or childhood cancers have been observed within the family, or this variant has already been detected in other families with childhood cancers, or this variant corresponds to a dominant-negative missense variant. ${ }^{* *}$ The first scan should be conducted with I.V. Gadolinium enhancement; in children, brain MRI should alternate with the Whole-Body MRI, so that the brain is imaged at least every six months.

\section{Impact of a Germline Disease-Causing TP53 Variant on Genetic Counselling}

Detection of a germline disease-causing TP53 variant in a breast cancer patient has not only major medical impact for herself but for their relatives. The variability of the age of tumour-onset observed in TP53 variant carriers, even within a family, complicates genetic counselling. Indeed, in carriers, the benefit of the annual surveillance program should be evaluated in the perspective of TP53 variant incomplete penetrance and the psychological burden induced by an intensive annual medical follow-up starting in childhood. The first international guidelines, based on the Toronto protocol [59] 
and published in 2017 [60], recommended to offer systematically the same surveillance protocol and therefore pre-symptomatic testing in childhood since the first year of age. However, the increasing number of germline TP53 variants detected in cancer patients without familial history, the incomplete and variable penetrance of the variants, the observation that only a fraction of variant carriers have access to this protocol, especially in US, lead us to propose a more stratified protocol in the framework of the European Reference Network GENTURIS, in order to help decision making [14]. For instance, when a germline TP53 pathogenic variant is detected in a patient with a breast cancer at 29 years of age without familial history, or in a 44-year breast cancer patient whose mother developed a sarcoma at 51, should we systematically offer pre-symptomatic testing in childhood since the first year of age? In the recently published European guideline [14], we recommend systematic pre-symptomatic testing and the intensive protocol in childhood from birth, under the following conditions: childhood cancers have been observed within the family, or this variant has already been detected in other families with childhood cancers, or this variant corresponds to a dominant-negative missense variant. If these conditions are not observed, we do not systematically recommend pre-symptomatic testing and complete annual medical follow-up since the first year of age. We think nevertheless that testing children in families with only early-onset adult cancers can be considered, but only after careful discussion with the parents in order to address the burden, and uncertain benefits, of surveillance in childhood [14]. The complexity of genetic counselling in families with germline TP53 variant carriers constitutes an additional argument highlighting the need to address the question of TP53 testing in the framework of a multi-disciplinary team.

\section{Psychological Considerations}

Given the variability, potential high penetrance and early onset of disease associated with TP53 pathogenic variants, individuals with this diagnosis may need additional psychosocial support to deal with distress and bereavement linked to cancer diagnoses in them and/or their family [69]. In contrast to the detection of a causal germline alteration in the other main breast cancer genes such as BRCA1, BRCA2 or PALB2, identification of a germline disease-causing TP53 variant in a patient with breast cancer may have an impact in her children under 18 years of age. Furthermore, genetic counselling, with further information on financial/insurance implications is necessary to ensure an informed decision has been made with regard to surveillance adherence.

\section{Conclusions}

Testing women with breast cancer for TP53 variants is not a straightforward decision. From the above, it can be seen that women identified as carriers of disease-causing TP53 variants have a lifelong indication for a heavy surveillance protocol (Table 2). The identification of a disease-causing TP53 variants variant will also affect their treatment with a decision on whether to opt not just for unilateral but bilateral mastectomy and will have important consequences, in terms of genetic counselling, sometimes in children before 18 years of age. It is clearly vital that any testing of TP53 results in a robust analysis of the variant by a laboratory with expert experience and using the most up to date criteria [22]. A complex situation is represented by the detection of a class three variant in a patient with breast cancer. If the variant remains a class 3 despite expert analysis and if the clinical presentation is strongly suggestive of a germline disease-causing TP53 variant, we think that it is safer to ensure in the patient the recommended follow-up with a regular update of the variant classification. In contrast, without certainty of the variant disease-causing role, prophylactic mastectomy should not be considered, and pre-symptomatic testing in relatives should not be performed, according to the rules of medical genetics. The most complicated issue in this situation remains the question of radiotherapy which should be discussed, case by case, by a multi-disciplinary team, including expertise in TP53.

As indicated in Table 3, the decision of TP53 testing in a patient with breast cancer should be based first on the updated Chompret criteria (Table 1), which constitute a formal indication. 
Table 3. Germline TP53 testing in Women with Breast Tumour.

\begin{tabular}{|c|c|}
\hline Age of Breast Tumour Onset & Presentation \\
\hline \multicolumn{2}{|c|}{ When TP53 testing should systematically be performed } \\
\hline Before 31 & Invasive breast carcinoma ${ }^{a}$ or ductal carcinoma in situ (DCIS) \\
\hline Before 36 & $\begin{array}{ll}- & \text { Bilateral invasive breast carcinoma or DCIS } \\
\text { - } & \text { or Multifocal invasive breast carcinoma or DCIS } \\
\text { - } & \text { or HER2+ invasive breast carcinoma or DCIS } \\
\text { - } & \text { Phyllode tumour }\end{array}$ \\
\hline Before 46 & $\begin{array}{l}\text { - Invasive breast carcinoma and a second TP53 core tumour } \\
\text { in the patient a } \\
\text { - } \\
\text { or invasive breast carcinoma and one first- or second-degree } \\
\text { relative with a TP53 core tumour before } 56 \text { years }{ }^{\mathrm{a}, \mathrm{b}}\end{array}$ \\
\hline \multicolumn{2}{|r|}{ When TP53 testing may be offered } \\
\hline Before 46 & $\begin{array}{l}\text { - } \quad \text { Bilateral invasive breast carcinoma } \\
\text { - } \quad \text { or HER } 2+\text { invasive breast carcinoma and a familial history } \\
\text { of HER } 2+\text { breast cancer }\end{array}$ \\
\hline \multicolumn{2}{|r|}{ When TP53 testing should not be performed } \\
\hline After 46 & $\begin{array}{l}\text { No previous TP53 core tumour before } 46 \text { and no familial history } \\
\text { fulfilling Chompret criteria }\end{array}$ \\
\hline
\end{tabular}

Besides the Chompret criteria, in breast cancer patients, this decision should also integrate the combination of several parameters including age of tumour-onset, histopathological characteristics, multifocal type, and familial history of cancers, which justifies extending the Chompret criteria in breast cancer patients (Table 3). Given (i) the very low rate of clearly disease-causing TP53 variants aged in women with breast cancer aged $>46$, (ii) the reasonably high chance of a variant of uncertain significance that could be misclassified and (iii) the increasing likelihood of clonal haematopoiesis, we consider that women presenting with breast cancer after 46 years, without personal or familial history, fulfilling the "Chompret Criteria" should not be tested using a breast panel that includes TP53 (Table 3). We also recommend that any patient presenting with isolated breast cancer not fulfilling the criteria presented in Table 3 and in whom a TP53 variant has been identified, should be referred to an expert genetics service that can interpret its true meaning and to a multi-disciplinary team for discussion [14]. This will ensure validation that will classify the variant accurately according to ACMG/AMP criteria and distinguish true hTP53rc from CHIP and erroneous classification as hTP53rc.

Author Contributions: All authors have contributed to the conception and writing of this review. All authors have read and agreed to the published version of the manuscript.

Funding: D.G.E. and E.R.W. are supported by the Manchester NIHR Biomedical Research Centre (IS-BRC1215-20007).

Acknowledgments: This work is supported (not financially) by the European Reference Network on Genetic Tumour Risk Syndromes (ERN GENTURIS) —Project ID No 739547. ERN GENTURIS is partly co-funded by the European Union within the framework of the Third Health Programme "ERN-2016-Framework Partnership Agreement 2017-2021". T.F. acknowledges his collaborators and, in particular, Gaelle Bougeard, Edwige Kasper, Stephanie Baert-Desurmont and Isabelle Tournier for their contribution.

Conflicts of Interest: The authors declare no conflict of interest. 


\section{Abbreviations}

$\begin{array}{ll}\text { ACMG } & \text { American College of Medical Genetics and Genomics } \\ \text { AMP } & \text { Association for Molecular Pathology } \\ \text { DCIS } & \text { ductal carcinoma in situ } \\ \text { ERN } & \text { European Reference Network } \\ \text { GENTURIS } & \text { Genetic tumour risk syndromes } \\ \text { hTP53rc } & \text { heritable TP53-related cancer } \\ \text { LFS } & \text { Li-Fraumeni syndrome } \\ \text { WBMRI } & \text { Whole-Body MRI }\end{array}$

\section{References}

1. Malkin, D.; Li, F.P.; Strong, L.C.; Fraumeni, J.F., Jr.; Nelson, C.E.; Kim, D.H.; Kassel, J.; Gryka, M.A.; Bischoff, F.Z.; Tainsky, M.A.; et al. Germ line p53 mutations in a familial syndrome of breast cancer, sarcomas, and other neoplasms. Science 1990, 250, 1233-1238. [CrossRef]

2. Srivastava, S.; Zou, Z.Q.; Pirollo, K.; Blattner, W.; Chang, E.H. Germ-line transmission of a mutated p53 gene in a cancer-prone family with Li-Fraumeni syndrome. Nature 1990, 348, 747-749. [CrossRef]

3. Li, F.P.; Fraumeni, J.F., Jr. Soft-tissue sarcomas, breast cancer, and other neoplasms. A familial syndrome? Ann. Intern. Med. 1969, 71, 747-752. [CrossRef]

4. Lynch, H.T.; Guirgis, H.A. Childhood cancer and the SBLA syndrome. Med. Hypotheses 1979, 5, 15-22. [CrossRef]

5. Varley, J.M.; McGown, G.; Thorncroft, M.; James, L.A.; Margison, G.P.; Forster, G. Are there low-penetrance TP53 Alleles? Evidence from childhood adrenocortical tumors. Am. J. Hum. Genet. 1999, 65, 995-1006. [CrossRef]

6. Tabori, U.; Shlien, A.; Baskin, B.; Levitt, S.; Ray, P.; Alon, N.; Hawkins, C.; Bouffet, E.; Pienkowska, M.; Lafay-Cousin, L.; et al. TP53 alterations determine clinical subgroups and survival of patients with choroid plexus tumors. J. Clin. Oncol. 2010, 28, 1995-2001. [CrossRef] [PubMed]

7. Magnusson, S.; Gisselsson, D.; Wiebe, T.; Kristoffersson, U.; Borg, Å.; Olsson, H. Prevalence of germline TP53 mutations and history of Li-Fraumeni syndrome in families with childhood adrenocortical tumors, choroid plexus tumors, and rhabdomyosarcoma: A population-based survey. Pediatr. Blood Cancer 2012, 59, 846-853. [CrossRef]

8. Hettmer, S.; Archer, N.M.; Somers, G.R.; Novokmet, A.; Wagers, A.J.; Diller, L.; Rodriguez-Galindo, C.; Teot, L.A.; Malkin, D. Anaplastic rhabdomyosarcoma in TP53 germline mutation carriers. Cancer 2014, 120, 1068-1075. [CrossRef] [PubMed]

9. Evans, D.G.; Moran, A.; Hartley, R.; Dawson, J.; Bulman, B.; Knox, F.; Howell, A.; Lalloo, F. Long-term outcomes of breast cancer in women aged 30 years or younger, based on family history, pathology and BRCA1/BRCA2/TP53 status. Br. J. Cancer 2010, 102, 1091-1098. [CrossRef] [PubMed]

10. Gonzalez, K.D.; Noltner, K.A.; Buzin, C.H.; Gu, D.; Wen-Fong, C.Y.; Nguyen, V.Q.; Han, J.H.; Lowstuter, K.; Longmate, J.; Sommer, S.S.; et al. Beyond Li Fraumeni Syndrome: Clinical characteristics of families with p53 germline mutations. J. Clin. Oncol. 2009, 7, 250-256. [CrossRef] [PubMed]

11. Ruijs, M.W.; Verhoef, S.; Rookus, M.A.; Pruntel, R.; van der Hout, A.H.; Hogervorst, F.B.; Kluijt, I.; Sijmons, R.H.; Aalfs, C.M.; Wagner, A.; et al. TP53 germline mutation testing in 180 families suspected of Li-Fraumeni syndrome: Mutation detection rate and relative frequency of cancers in different familial phenotypes. J. Med. Genet. 2010, 47, 421-428. [CrossRef] [PubMed]

12. Bougeard, G.; Renaux-Petel, M.; Flaman, J.M.; Charbonnier, C.; Fermey, P.; Belotti, M.; Gauthier-Villars, M.; Stoppa-Lyonnet, D.; Consolino, E.; Brugières, L.; et al. Revisiting Li-Fraumeni Syndrome from TP53 Mutation Carriers. J. Clin. Oncol. 2015, 33, 2345-2352. [CrossRef] [PubMed]

13. Renaux-Petel, M.; Charbonnier, F.; Théry, J.C.; Fermey, P.; Lienard, G.; Bou, J.; Coutant, S.; Vezain, M.; Kasper, E.; Fourneaux, S.; et al. Contribution of de novo and mosaic TP53 mutations to Li-Fraumeni syndrome. J. Med. Genet. 2018, 55, 173-180. [CrossRef] [PubMed]

14. Frebourg, T.; Bajalica Lagercrantz, S.; Oliveira, C.; Magenheim, R.; Evans, D.G.; European Reference Network GENTURIS. Guidelines for the Li-Fraumeni and heritable TP53-related cancer syndromes. Eur. J. Hum. Genet. 2020, 28, 1379-1386. [CrossRef] [PubMed] 
15. Richards, S.; Aziz, N.; Bale, S.; Bick, D.; Das, S.; Gastier-Foster, J.; Grody, W.W.; Hegde, M.; Lyon, E.; Spector, E.; et al. Standards and guidelines for the interpretation of sequence variants: A joint consensus recommendation of the American College of Medical Genetics and Genomics and the Association for Molecular Pathology. Genet. Med. 2015, 17, 405-424. [CrossRef]

16. Karczewski, K.J.; Francioli, L.C.; Tiao, G.; Cummings, B.B.; Alföldi, J.; Wang, Q.; Collins, R.L.; Laricchia, K.M.; Ganna, A.; Birnbaum, D.P.; et al. The mutational constraint spectrum quantified from variation in 141,456 humans. Nature 2020, 581, 434-443. [CrossRef]

17. Kato, S.; Han, S.Y.; Liu, W.; Otsuka, K.; Shibata, H.; Kanamaru, R.; Ishioka, C. Understanding the function-structure and function-mutation relationships of $\mathrm{p} 53$ tumor suppressor protein byhigh-resolution missense mutation analysis. Proc. Natl. Acad. Sci. USA 2003, 100, 8424-8429. [CrossRef]

18. Kotler, E.; Shani, O.; Goldfeld, G.; Lotan-Pompan, M.; Tarcic, O.; Gershoni, A.; Hopf, T.A.; Marks, D.S.; Oren, M.; Segal, E. A Systematic p53 Mutation Library Links Differential Functional Impact to Cancer Mutation Pattern and Evolutionary Conservation. Mol. Cell. 2018, 71, 178-190. [CrossRef]

19. Giacomelli, A.O.; Yang, X.; Lintner, R.E.; McFarland, J.M.; Duby, M.; Kim, J.; Howard, T.P.; Takeda, D.Y.; Ly, S.H.; Kim, E.; et al. Mutational processes shape the landscape of TP53 mutations in human cancer. Nat. Genet. 2018, 50, 1381-1387. [CrossRef]

20. Bouaoun, L.; Sonkin, D.; Ardin, M.; Hollstein, M.; Byrnes, G.; Zavadil, J.; Olivier, M. TP53 Variations in Human Cancers: New Lessons from the IARC TP53 Database and Genomics Data. Hum. Mutat. 2016, 37, 865-876. [CrossRef]

21. Raad, S.; Rolain, M.; Coutant, S.; Derambure, C.; Lanos, R.; Charbonnier, F.; Bou, J.; Bouvignies, E.; Lienard, G.; Vasseur, S.; et al. A blood functional assay for rapid clinical interpretation of germline TP53 variants. J. Med. Genet. 2020. [CrossRef]

22. Fortuno, C.; Lee, K.; Olivier, M.; Pesaran, T. Germline TP53 variants. Specifications of the ACMG/AMP variant interpretation guidelines for germline TP53 variants. Hum. Mutat. 2020, in press. [CrossRef] [PubMed]

23. de Andrade, K.C.; Frone, M.N.; Wegman-Ostrosky, T.; Khincha, P.P.; Kim, J.; Amadou, A.; Santiago, K.M.; Fortes, F.P.; Lemonnier, N.; Mirabello, L.; et al. Variable population prevalence estimates of germline TP53 variants: A gnomAD-based analysis. Hum. Mutat. 2019, 40, 97-105. [CrossRef] [PubMed]

24. Evans, D.G.; Turnbull, C.; Woodward, E.R. Concern regarding classification of germline TP53 variants as likely pathogenic. Hum. Mutat. 2019, 40, 828-831. [CrossRef] [PubMed]

25. Lalloo, F.; Varley, J.; Ellis, D.; Moran, A.; O’Dair, L.; Pharoah, P.; Evans, D.G. Early Onset Breast Cancer Study Group. Prediction of pathogenic mutations in patients with early-onset breast cancer by family history. Lancet 2003, 361, 1101-1102. [CrossRef]

26. Frebourg, T.; Lagercrantz, S.B.; Oliveira, C.; Magenheim, R.; Evans, D.G.; European Reference Network GENTURIS. Reply to Kratz et al. Eur. J. Hum. Genet. 2020, 28, 1483-1485. [CrossRef]

27. Yurgelun, M.B.; Masciari, S.; Joshi, V.A.; Mercado, R.C.; Lindor, N.M.; Gallinger, S.; Hopper, J.L.; Jenkins, M.A.; Buchanan, D.D.; Newcomb, P.A.; et al. Germline TP53 mutations in patients with early-onset colorectal cancer in the colon cancer family registry. JAMA Oncol. 2015, 1, 214-221. [CrossRef]

28. Evans, D.G.; Hartley, C.L.; Smith, P.T.; King, A.T.; Bowers, N.L.; Tobi, S.; Wallace, A.J.; Perry, M.; Anup, R.; Lloyd, S.K.W.; et al. Incidence of mosaicism in 1055 de novo NF2 cases: Much higher than previous estimates with high utility of next-generation sequencing. Genet. Med. 2020, 22, 53-59. [CrossRef]

29. Weitzel, J.N.; Chao, E.C.; Nehoray, B.; Van Tongeren, L.R.; LaDuca, H.; Blazer, K.R.; Slavin, T.; Facmg, D.A.B.M.D.; Pesaran, T.; Rybak, C.; et al. Somatic TP53 variants frequently confound germ-line testing results. Genet. Med. 2018, 20, 809-816. [CrossRef]

30. Weber-Lassalle, K.; Harter, P.; Hauke, J.; Ernst, C.; Kommoss, S.; Marmé, F.; Weber-Lassalle, N.; Prieske, K.; Dietrich, D.; Borde, J.; et al. Diagnosis of Li-Fraumeni Syndrome: Differentiating TP53 germline mutations from clonal hematopoiesis: Results of the observational AGO-TR1 trial. Hum. Mutat. 2018, 39, 2040-2046. [CrossRef]

31. Chen, S.; Liu, Y. p53 involvement in clonal hematopoiesis of indeterminate potential. Curr. Opin. Hematol. 2019, 4, 235-240. [CrossRef] [PubMed] 
32. Batalini, F.; Peacock, E.G.; Stobie, L.; Robertson, A.; Garber, J.; Weitzel, J.N.; Tung, N.M. Li-Fraumeni syndrome: Not a straightforward diagnosis anymore-the interpretation of pathogenic variants of low allele frequency and the differences between germline PVs, mosaicism, and clonal hematopoiesis. Breast Cancer Res. 2019, 21, 107. [CrossRef] [PubMed]

33. Swisher, E.M.; Wollan, M.; Mahtani, S.M.; Willner, J.B.; Garcia, R.; Goff, B.A.; King, M.C. Tumor-specific p53 sequences in blood and peritoneal fluid of women with epithelial ovarian cancer. Am. J. Obstet. Gynecol. 2005, 193, 662-667. [CrossRef] [PubMed]

34. Chompret, A.; Brugières, L.; Ronsin, M.; Gardes, M.; Dessarps-Freichey, F.; Abel, A.; Hua, D.; Ligot, L.; Dondon, M.G.; Bressac-de Paillerets, B. P53 germline mutations in childhood cancers and cancer risk for carrier individuals. Br. J. Cancer 2000, 82, 1932-1937. [PubMed]

35. Mai, P.L.; Best, A.F.; Peters, J.A.; DeCastro, R.M.; Khincha, P.P.; Loud, J.T.; Bremer, R.C.; Rosenberg, P.S.; Savage, S.A. Risks of first and subsequent cancers among TP53 mutation carriers in the National Cancer Institute Li-Fraumeni syndrome cohort. Cancer. 2016, 122, 3673-3681. [CrossRef] [PubMed]

36. Amadou, A.; Waddington Achatz, M.I.; Hainaut, P. Revisiting tumor patterns and penetrance in germline TP53 mutation carriers: Temporal phases of Li-Fraumeni syndrome. Curr. Opin. Oncol. 2018, 30, $23-29$. [CrossRef]

37. Dorling, L.; Carvalho, S.; Allen, J. Breast cancer risk genes: Association analysis of rare coding variants in 34 genes in 60,466 cases and 53,461 controls. N. Engl. J. Med. 2020, in press.

38. Shin, S.J.; Dodd-Eaton, E.B.; Peng, G.; Bojadzieva, J.; Chen, J.; Amos, C.I.; Frone, M.N.; Khincha, P.P.; Mai, P.L.; Savage, S.A.; et al. Penetrance of different cancer types in families with Li-Fraumeni syndrome: A validation study using multi-center cohorts. Cancer Res. 2020, 80, 354-360. [CrossRef]

39. Zelada-Hedman, M.; Børresen-Dale, A.L.; Claro, A.; Chen, J.; Skoog, L.; Lindblom, A. Screening for TP53 mutations in patients and tumours from 109 Swedish breast cancer families. Br. J. Cancer 1997, 75, 1201-1204. [CrossRef]

40. Rath, M.G.; Masciari, S.; Gelman, R.; Miron, A.; Miron, P.; Foley, K.; Richardson, A.L.; Krop, I.E.; Verselis, S.J.; Dillon, D.A.; et al. Prevalence of germline TP53 mutations in HER2+ breast cancer patients. Breast Cancer Res. Treat. 2013, 139, 193-198. [CrossRef]

41. Hyder, Z.; Harkness, E.F.; Woodward, E.R.; Bowers, N.L.; Pereira, M.; Wallace, A.J.; Howell, S.J.; Howell, A.; Lalloo, F.; Newman, W.G.; et al. Risk of Contralateral Breast Cancer in Women with and without Pathogenic Variants in BRCA1, BRCA2, and TP53 Genes in Women with Very Early-Onset ( $<36$ Years) Breast Cancer. Cancers 2020, 12, 378. [CrossRef]

42. Figueiredo, B.C.; Sandrini, R.; Zambetti, G.P.; Pereira, R.M.; Cheng, C.; Liu, W.; Lacerda, L.; Pianovski, M.A.; Michalkiewicz, E.; Jenkins, J.; et al. Penetrance of adrenocortical tumours associated with the germline TP53 R337H mutation. J. Med. Genet. 2006, 43, 91-96. [CrossRef]

43. Achatz, M.I.; Olivier, M.; Le Calvez, F.; Martel-Planche, G.; Lopes, A.; Rossi, B.M.; Ashton-Prolla, P.; Giugliani, R.; Palmero, E.I.; Vargas, F.R.; et al. The TP53 mutation, R337H, is associated with Li-Fraumeni and Li-Fraumeni-like syndromes in Brazilian families. Cancer Lett. 2007, 245, 96-102. [CrossRef] [PubMed]

44. Palmero, E.I.; Schüler-Faccini, L.; Caleffi, M.; Achatz, M.I.; Olivier, M.; Martel-Planche, G.; Marcel, V.; Aguiar, E.; Giacomazzi, J.; Ewald, I.P.; et al. Detection of R337H, a germline TP53 mutation predisposing to multiple cancers, in asymptomatic women participating in a breast cancer screening program in Southern Brazil. Cancer Lett. 2008, 261, 21-25. [CrossRef] [PubMed]

45. Andrade, K.C.; Santiago, K.M.; Fortes, F.P.; Mambelli, L.I.; Nóbrega, A.F.; Achatz, M.I. Early-onset breast cancer patients in the South and Southeast of Brazil should be tested for the TP53 p.R337H mutation. Genet. Mol. Biol. 2016, 39, 199-202. [CrossRef] [PubMed]

46. Zerdoumi, Y.; Lanos, R.; Raad, S.; Flaman, J.M.; Bougeard, G.; Frebourg, T.; Tournier, I. Germline TP53 mutations result into a constitutive defect of p53 DNA binding and transcriptional response to DNA damage. Hum. Mol. Genet. 2017, 26, 2591-2602. [CrossRef]

47. Fortuno, C.; James, P.A.; Spurdle, A.B. Current review of TP53 pathogenic germline variants in breast cancer patients outside Li-Fraumeni syndrome. Hum. Mutat. 2018, 39, 1764-1773. [CrossRef]

48. Bakhuizen, J.J.; Hogervorst, F.B.; Velthuizen, M.E.; Ruijs, M.W.; van Engelen, K.; van Os, T.A.; Gille, J.J.; Collée, M.; van den Ouweland, A.M.; van Asperen, C.J.; et al. TP53 germline mutation testing in early-onset breast cancer: Findings from a nationwide cohort. Fam. Cancer 2019, 18, 273-280. [CrossRef] 
49. Melhem-Bertrandt, A.; Bojadzieva, J.; Ready, K.J.; Obeid, E.; Liu, D.D.; Gutierrez-Barrera, A.M.; Litton, J.K.; Olopade, O.I.; Hortobagyi, G.N.; Strong, L.C.; et al. Early onset HER2-positive breast cancer is associated with germline TP53 mutations. Cancer 2012, 118, 908-913. [CrossRef]

50. Rana, H.Q.; Gelman, R.; LaDuca, H.; McFarland, R.; Dalton, E.; Thompson, J.; Speare, V.; Dolinsky, J.S.; Chao, E.C.; Garber, J.E. Differences in TP53 Mutation Carrier Phenotypes Emerge From Panel-Based Testing. J. Natl. Cancer Inst. 2018, 110, 863-870. [CrossRef]

51. Wilson, J.R.; Bateman, A.C.; Hanson, H.; An, Q.; Evans, G.; Rahman, N.; Jones, J.L.; Eccles, D.M. A novel HER2-positive breast cancer phenotype arising from germline TP53 mutations. J. Med. Genet. 2010, 47, 771-774. [CrossRef]

52. Masciari, S.; Dillon, D.A.; Rath, M.; Robson, M.; Weitzel, J.N.; Balmana, J.; Gruber, S.B.; Ford, J.M.; Euhus, D.; Lebensohn, A.; et al. Breast cancer phenotype in women with TP53 germline mutations: A Li-Fraumeni syndrome consortium effort. Breast Cancer Res. Treat. 2012, 133, 1125-1130. [CrossRef]

53. Kuba, M.G.; Lester, S.C.; Bowman, T.; Stokes, S.M.; Taneja, K.L.; Garber, J.E.; Dillon, D.A. Histopathologic features of breast cancer in Li-Fraumeni syndrome. Mod. Pathol. 2020. Online ahead of print. [CrossRef] [PubMed]

54. Fortuno, C.; Mester, J.; Pesaran, T.; Weitzel, J.N.; Dolinsky, J.; Yussuf, A.; McGoldrick, K.; Garber, J.E.; Savage, S.A.; Khincha, P.P.; et al. Suggested application of HER2+ breast tumor phenotype for germline TP53 variant classification within ACMG/AMP guidelines. Hum. Mutat. 2020, 41, 1555-1562. [CrossRef] [PubMed]

55. Birch, J.M.; Alston, R.D.; McNally, R.J.; Evans, D.G.; Kelsey, A.M.; Harris, M.; Eden, O.B.; Varley, J.M. Relative frequency and morphology of cancers in carriers of germline TP53 mutations. Oncogene 2001, 20, 4621-4628. [CrossRef] [PubMed]

56. Giacomazzi, J.; Koehler-Santos, P.; Palmero, E.I.; Graudenz, M.S.; Rivero, L.F.; Lima, E.; Pütten, A.C.; Hainaut, P.; Camey, S.A.; Michelli, R.D.; et al. A TP53 founder mutation, p.R337H, is associated with phyllodes breast tumors in Brazil. Virchows Arch. 2013, 463, 17-22. [CrossRef]

57. Rosenberger, L.H.; Thomas, S.M.; Nimbkar, S.N.; Hieken, T.J.; Ludwig, K.K.; Jacobs, L.K.; Miller, M.E.; Gallagher, K.K.; Wong, J.; Neuman, H.B.; et al. Germline Genetic Mutations in a Multi-center Contemporary Cohort of 550 Phyllodes Tumors: An Opportunity for Expanded Multi-gene Panel Testing. Ann. Surg. Oncol. 2020, 27, 3633-3640. [CrossRef]

58. Kasper, E.; Angot, E.; Colasse, E.; Nicol, L.; Sabourin, J.C.; Adriouch, S.; Lacoume, Y.; Charbonnier, C.; Raad, S.; Frebourg, T.; et al. Contribution of genotoxic anticancer treatments to the development of multiple primary tumours in the context of germline TP53 mutations. Eur. J. Cancer 2018, 101, 254-262. [CrossRef]

59. Villani, A.; Shore, A.; Wasserman, J.D.; Stephens, D.; Kim, R.H.; Druker, H.; Gallinger, B.; Naumer, A.; Kohlmann, W.; Novokmet, A.; et al. Biochemical and imaging surveillance in germline TP53 mutation carriers with Li-Fraumeni syndrome: 11 year follow-up of a prospective observational study. Lancet Oncol. 2016, 17, 1295-1305. [CrossRef]

60. Kratz, C.P.; Achatz, M.I.; Brugières, L.; Frebourg, T.; Garber, J.E.; Greer, M.C.; Hansford, J.R.; Janeway, K.A.; Kohlmann, W.K.; McGee, R.; et al. Cancer Screening Recommendations for Individuals with Li-Fraumeni Syndrome. Clin. Cancer Res. 2017, 23, e38-e45. [CrossRef]

61. Hanson, H.; Brady, A.F.; Crawford, G.; Eeles, R.A.; Gibson, S.; Jorgensen, M.; Izatt, L.; Sohaib, A.; Tischkowitz, M.; Evans, D.G.; et al. UKCGG Consensus Group guidelines for the management of patients with constitutional TP53 pathogenic variants. J. Med. Genet. 2020. [CrossRef]

62. Ballinger, M.L.; Best, A.; Mai, P.L.; Khincha, P.P.; Loud, J.T.; Peters, J.A.; Achatz, M.I.; Chojniak, R.; Balieiro da Costa, A.; Santiago, K.M.; et al. Baseline Surveillance in Li-Fraumeni Syndrome Using Whole-Body Magnetic Resonance Imaging: A Meta-analysis. JAMA Oncol. 2017, 3, 1634-1639. [CrossRef]

63. Caron, O.; Frebourg, T.; Benusiglio, P.R.; Foulon, S.; Brugières, L. Lung Adenocarcinoma as Part of the Li-Fraumeni Syndrome Spectrum: Preliminary Data of the LIFSCREEN Randomized Clinical Trial. JAMA Oncol. 2017, 3, 1736-1737. [CrossRef]

64. Ruijs, M.W.G.; Loo, C.E.; van Buchem, C.A.J.M.; Bleiker, E.M.A.; Sonke, G.S. Surveillance of Dutch Patients with Li-Fraumeni Syndrome: The LiFe-Guard Study. JAMA Oncol. 2017, 3, 1733-1734. [CrossRef] [PubMed]

65. Saya, S.; Killick, E.; Thomas, S.; Taylor, N.; Bancroft, E.K.; Rothwell, J.; Benafif, S.; Dias, A.; Mikropoulos, C.; Pope, J.; et al. Baseline results from the UK SIGNIFY study: A whole-body MRI screening study in TP53 mutation carriers and matched controls. Fam. Cancer 2017, 16, 433-440. [CrossRef] [PubMed] 
66. Bojadzieva, J.; Amini, B.; Day, S.F.; Jackson, T.L.; Thomas, P.S.; Willis, B.J.; Throckmorton, W.R.; Daw, N.C.; Bevers, T.B.; Strong, L.C. Whole body magnetic resonance imaging (WB-MRI) and brain MRI baseline surveillance in TP53 germline mutation carriers: Experience from the Li-Fraumeni Syndrome Education and Early Detection (LEAD) clinic. Fam. Cancer 2018, 17, 287-294. [CrossRef]

67. O'Neill, A.F.; Voss, S.D.; Jagannathan, J.P.; Kamihara, J.; Nibecker, C.; Itriago-Araujo, E.; Masciari, S.; Parker, E.; Barreto, M.; London, W.B.; et al. Screening with whole-body magnetic resonance imaging in pediatric subjects with Li-Fraumeni syndrome: A single institution pilot study. Pediatr. Blood Cancer 2018, 65. [CrossRef]

68. Paixao, D.; Guimaraes, M.D.; de Andrade, K.C.; Nobrega, A.F.; Chojniak, R.; Achatz, M.I. Whole-body magnetic resonance imaging of Li-Fraumeni syndrome patients: Observations from a two rounds screening of Brazilian patients. Cancer Imaging 2018, 18, 27. [CrossRef]

69. Lammens, C.R.; Aaronson, N.K.; Wagner, A.; Sijmons, R.H.; Ausems, M.G.; Vriends, A.H.; Ruijs, M.W.; van Os, T.A.; Spruijt, L.; Gómez García, E.B.; et al. Genetic testing in Li-Fraumeni syndrome: Uptake and psychosocial consequences. J. Clin. Oncol. 2010, 28, 3008-3014. [CrossRef] [PubMed]

Publisher's Note: MDPI stays neutral with regard to jurisdictional claims in published maps and institutional affiliations.

(C) 2020 by the authors. Licensee MDPI, Basel, Switzerland. This article is an open access article distributed under the terms and conditions of the Creative Commons Attribution (CC BY) license (http://creativecommons.org/licenses/by/4.0/). 